\title{
Sport Utility Vehicle (SUV) Rollover Collisions: An Analysis of NASS - CDS Injury Data for 1998 through 2004
}

\author{
Orion P. Keifer, Jr. and Orion P. Keifer \\ Applications Engineering Group, Inc. \\ Michael L. Woodhouse \\ Biodynamic Research Laboratories, Inc.
}

Copyright $(2007$ SAE International

\begin{abstract}
Rollover collisions are very complex and the subject of significant interest. Roll-over collisions involving Sport Utility Vehicles (SUV) are of particular interest due to their high center of gravity (increased propensity for rollover) and recent surge in popularity. The following research examines SUV rollover collisions documented in the National Automotive Sampling System (NASS) Crashworthiness Data System (CDS) for the years 1998 through 2004. The NASS/CDS was initially screened for SUV rollover collisions, then screened to eliminate soft top vehicles, such as the Jeep Wrangler and Suzuki Samurai. The injury data was further limited to driving age teens and adults (age 16 and older) in the front outboard seating positions. The data was evaluated with respect to injury severity using the Abbreviated Injury Scale (AIS), roof crush, seatbelt usage, seated position in the vehicle and with respect to roll direction (far-side/near-side), ejection status and crash severity measured by number of quarter turns of the vehicle. The data shows that ejection is the best single predictor of serious or fatal injury and that seatbelts are highly effective in preventing ejection. Further, seatbelted occupants have significantly less severe injuries than their non-seatbelted non-ejected counterparts, regardless of roll direction and number of rolls. As a general trend, non-ejected seatbelted occupants had a lower fraction of MAIS 3 and above injuries than their non-seatbelted nonejected counterparts for various categories of roof crush depth; however, not all categories reached a $\mathrm{p}<0.05$ level of significance.
\end{abstract}

\section{INTRODUCTION}

Rollover collisions are complex as compared to their planar counterparts because they involve six degrees of freedom, as opposed to three. Yet, the number of staged rollover crashes are relatively sparse and therefore substantial information must be derived from historical crash data. Concerning injury, several variables have been considered in the past generally evaluating data from the National Automotive Sampling System (NASS) Crashworthiness Data System (CDS), and the Fatal Accident Reporting System (FARS). It has been shown, for example, that the injury incidence and severity is substantially higher for ejected occupants, as opposed to non-ejected occupants. Paranteau, et. al. (2000) concluded that "for unbelted drivers, the rate to be seriously injured was 10 times higher when completely ejected than non-ejected. Furthermore, for non-ejected drivers, the rate of seriously injured [occupants] seemed higher when they were unbelted than belted". Esterlitcz et. al. (1989) found "single vehicle rollover crashes have the highest increase risk of death due to ejection: about eightfold for the driver and sevenfold for the right front passenger". Paranteau, et. al. (2001) divided the passengers into nearside and farside; where nearside was the seat ajacent to the roll direction. Based on the data presented, the ejection rate for unbelted passengers was approximately $25.4 \%$ (farside) and $23.1 \%$ (nearside). For belted drivers, the ejection rate was $1.8 \%$ (farside) and $2.1 \%$ (nearside). The seatbelt usage rate was reported at approximately $71 \%$. Considering only fatal crashes, Determann, et. al. (2002) reported a 
seatbelt usage of $73 \%$, with a $4 \%$ ejection rate of belted occupants and a 53\% ejection rate of unbelted occupants. Diggs, et. al. (1998) examined the rate of serious or fatal injuries for passenger cars and light trucks. They found that for seatbelted occupants in automobiles, fatal or serious injury occurred in $2.84 \%$ of belted occupants and $9.55 \%$ for unbelted occupants, a ratio of 3.36 for unbelted to belted occupant's serious/fatal injury rate. Similarly for light trucks, the serious/fatal injury rate for belted occupants was $1.8 \%$ and for unbelted occupants $11.01 \%$, an unbelted to belted serious/fatal injury ratio of 6.12. Freidman, et. al. (1998) reported that "although nearly half of the occupants were wearing safety belts, unrestrained occupants received more than four times as many serious to fatal injuries". Godrick (2002) examined injury data specifically for Sport Utility Vehicles (SUV's). His data indicates that the injury rate for unbelted occupants is approximately four times that of belted occupants, assuming a $67 \%$ seatbelt usage rate.

Of particular interest has been the effect of roof crush to the injury potential. Experimental testing with Hybrid III Anthropometric Test Devices (ATDs) has shown no significant increase in the incidence or severity of head/neck injuries and or load on ATDs, based on increased roof crush for similar rollover crashes with and without roll cages, Orlowski, et al (1985), Bahling, et. al. (1990) and Moffatt, et. al. (2003). Similar conclusions were reached by Paniali, et.al. (1998). Friedman, et.al. (1998) concludes that there is a correlation between increased roof crush and increased injury severity. They state "restraints improve the effective residual headroom by about seven centimeters. That is, a restrained occupant compared with an unrestrained occupant, can withstand as much as seven centimeters of additional roof crush without sustaining serious injury". Godrick (2002) in his study of SUV injury data concludes "when removing the ejected unbelted occupants [from consideration], roof associated contacts show similar trends for both belted and unbelted occupants."

With the increase in popularity of SUV's and their higher propensity to rollover, as opposed to the traditional automobile, specific investigation of SUV rollovers is warranted. The purpose of this research is to examine SUV rollovers and compare injury outcomes based on severity of the impact, as measured by quarter turns of roll and roof crush, effectiveness of the seatbelt in preventing ejection and injury, and ejection status on injury outcomes. Both exposure and criterion counts are included to give percentage of exposures which result in the criterion being met.

\section{METHODOLOGY AND RESULTS}

The National Automotive Sampling System (NASS) Crashworthiness Data System (CDS) for the years 1998 through 2004 was screened for SUV rollover collisions. The data was further screened to eliminate any open vehicles, such as the Jeep Wrangler and Suzuki Samurai; however, all model years of closed SUVs were included. The data was further screened to include only front seat outboard occupants. Only occupants that were 16 years of age or older were considered. The screening resulted in 1,087 vehicle crashes with 1,451 occupants being considered. All information is unweighted, which allows the reader to assess the number of data in each catagory. It should be noted that some occupant exposures had either missing or unknown data in one or more fields. While all occupant exposures were screened, those with insufficient data for a specific table were not included. Therefore, the total exposures listed in any given table may be less than 1451 .

Table 1 gives the breakdown of the collisions by direction of roll.

\begin{tabular}{|l|c|c|}
\hline \multicolumn{3}{|c|}{ Rollover collisions } \\
\hline Leading side & Vehicle count & $\%$ \\
\hline Driver's side & 573 & 52.7 \\
\hline Passenger's side & 440 & 40.4 \\
\hline Unknown & 68 & 6.3 \\
\hline End over end & 6 & 0.6 \\
\hline Total & 1,087 & \\
Table 1. Vehicle roll direction.
\end{tabular}

The collision roll severity is given in quarter turns of the vehicle. Data for this study is presented in Table 2. As can be seen, over half $(69.4 \%)$ of the rollover collisions, excluding unknown and endover-end collisions, resulted in one full roll or less. Of those, most were either one half roll with 
the final rest on the roof $(36.7 \%)$ or one full turn, with final rest on the wheels $(35.6 \%)$. Final rest on the side ( $1 / 4$ or $3 / 4$ roll) consituted only $29.1 \%$ of the one roll or less collisions. A small percentage $(5.9 \%)$ of the roll-over collisions, excluding unknown and end over end collisions, resulted in more than two full rolls.

\begin{tabular}{|c|c|c|}
\hline \multicolumn{3}{|c|}{ Rollover severity } \\
\hline $1 / 4$ turns of roll & Vehicle Count & $\%$ \\
\hline 1 & 102 & 10.4 \\
\hline 2 & 251 & 25.5 \\
\hline 3 & 87 & 8.8 \\
\hline 4 & 243 & 24.7 \\
\hline $5 / 6$ & 161 & 16.4 \\
\hline $7 / 8$ & 82 & 8.3 \\
\hline 9 to 12 & 49 & 0.9 \\
\hline Over 12 & 9 & -- \\
\hline Unknown & 97 & --- \\
\hline End over end & 6 & \\
\hline Total & 1,087 & 5.0 \\
\hline
\end{tabular}

Table 2. Collision roll severity (*unknown and end-over-end collisions omitted)

The occupants can be catagorized by position in the vehicle (driver or passenger) or by position with respect to the roll direction (near and far side, where near side is the seated position adjacent to

\begin{tabular}{|l|c|c|}
\hline \multicolumn{3}{|c|}{ Occupant position } \\
\hline Occupant position & Count & $\%$ \\
\hline Driver's seat & 1084 & 74.7 \\
\hline Passenger's seat & 367 & 25.3 \\
\hline Total & 1451 & \\
\hline
\end{tabular}

Table 3. Occupant position in the vehicle.

\begin{tabular}{|c|c|c|}
\hline \multicolumn{3}{|c|}{ Occupant position } \\
\hline Occupant position & Count & $\% *$ \\
\hline Near side & 735 & 54.5 \\
\hline Far side & 613 & 45.5 \\
\hline Unknown & 96 & --- \\
\hline End over end & 7 & --- \\
\hline Total & 1451 & \\
\hline
\end{tabular}

the leading side of the roll). The breakdown is given in Tables 3 and 4.

There was nearly three times as many drivers $(74.7 \%)$ as front seat passengers $(25.3 \%)$. This is expected since there must be a driver, but the passenger seat can be occupied, empty or occupied with a person under 16 years of age. Concerning the direction of roll of the occupants whose position is known, the distribution was more even, with $54.5 \%$ on the near side and $46.5 \%$ on the far side.

Seatbelt usage by position is noted in Tables 5 and 6.

\begin{tabular}{|l|c|c|c|c|}
\hline \multicolumn{4}{|c|}{ Occupant position with respect to the vehicle } \\
\hline & \multicolumn{2}{|c|}{ Seatbelted } & \multicolumn{2}{c|}{ Non-seatbelted } \\
\hline $\begin{array}{l}\text { Occupant } \\
\text { position }\end{array}$ & Count & $\%$ & Count & $\%$ \\
\hline $\begin{array}{l}\text { Driver's } \\
\text { seat }\end{array}$ & 765 & 73.1 & 282 & 26.9 \\
\hline $\begin{array}{l}\text { Passenger's } \\
\text { seat }\end{array}$ & 243 & 69.0 & 109 & 29.7 \\
\hline Total & 1008 & 72.1 & 391 & 27.9 \\
\hline
\end{tabular}

Table 5. Seatbelt usage as a function of passenger position in the vehicle.

\begin{tabular}{|l|c|c|c|c|c|c|}
\hline \multicolumn{6}{|c|}{ Occupant position with respect to the roll direction } \\
\hline & \multicolumn{2}{|c|}{ Seatbelted } & \multicolumn{2}{c|}{$\begin{array}{c}\text { Non- } \\
\text { seatbelted }\end{array}$} & \multicolumn{2}{c|}{ Unknown } \\
\hline $\begin{array}{l}\text { Occupant } \\
\text { position }\end{array}$ & Count & $\%$ & Count & $\%$ & Count & $\%$ \\
\hline Near side & 530 & 74.6 & 180 & 25.4 & 25 & --- \\
\hline Far side & 413 & 70.2 & 175 & 29.8 & 25 & --- \\
\hline Unknown & 65 & --- & 36 & --- & 2 & --- \\
\hline Total & 1008 & & 391 & & 52 & \\
\hline Table 6. Seatbelt usage as a function of passenger position with respect \\
to the roll direction.
\end{tabular}

As can be seen from Tables 5 and 6 , the seat belt usage was approximately $72 \%$, with the driver usage slightly higher and the passenger usage slightly lower. Similarly, the near side seatbelt usage was slightly higher than the far side.

Ejection from the vehicle is divided into three catagories: None, partial and full. Partial ejection includes cases where any portion of the body extends out of the vehicle passenger compartment, 
such as a head, trunk or an extremity. Ejection from the vehicle, based on the occupant seated position in the vehicle (driver or front seat passenger) and seatbelt usage is presented in Table 7. The seated position and ejected status is known for a total of 1255 exposures.

\begin{tabular}{|l|c|c|c|c|c|c|c|c|}
\hline \multicolumn{7}{|c|}{ Sjection of driver and passenger } \\
\hline & \multicolumn{7}{|c|}{ Seatbelted } & \multicolumn{4}{c|}{ Non-seatbelted } \\
\hline Eject. & Drive & Pass & Tot & $\%$ & Drive & Pass & Tot & $\%$ \\
\hline None & 668 & 118 & 786 & 91.0 & 128 & 60 & 188 & 48.1 \\
\hline Part. & 56 & 9 & 65 & 7.5 & 26 & 5 & 31 & 7.9 \\
\hline Full & 8 & 5 & 13 & 1.5 & 129 & 43 & 172 & 44.0 \\
\hline Total & 732 & 132 & 864 & & 283 & 108 & 391 & \\
\hline Table 7. & $\begin{array}{l}\text { Ejection status of occupants as a function of seated position in } \\
\text { the vehicle (driver or front seat passenger) and seatbelt usage. }\end{array}$
\end{tabular}

Ejection from the vehicle, based on the position of the occupant with respect to the roll direction and seatbelt usage is presented in Table 8. Note the seated position and ejected status is known for a total of 1287 exposures.

\begin{tabular}{|l|c|c|c|c|c|c|c|c|}
\hline \multicolumn{7}{|c|}{ Ejection, farside and nearside } \\
\hline & \multicolumn{3}{|c|}{ Seatbelted } & \multicolumn{4}{c|}{ Non-seatbelted } \\
\hline Eject. & Near & Far & Tot & $\%$ & Near & Far & Tot & $\%$ \\
\hline None & 490 & 372 & 862 & 92.5 & 92 & 79 & 171 & 48.2 \\
\hline Part. & 30 & 26 & 56 & 6.0 & 14 & 15 & 29 & 8.2 \\
\hline Full & 5 & 9 & 14 & 1.5 & 74 & 81 & 155 & 42.7 \\
\hline Total & 525 & 407 & 932 & 100 & 180 & 175 & 355 & \\
\hline
\end{tabular}

Table 8. Ejection status of occupants as a function of seated position with respect to the direction of roll and seatbelt ususage.

As can be seen from Tables 7 and 8 , seatbelts are highly effective in preventing ejection. Considering Table 8 data, only $7.5 \%$ of seatbelted occupants are either partially or fully ejected, as compaired to $51.2 \%$ for the non-seatbelted group. The benefit is overwhelming when it comes to full ejection, only $1.5 \%$ of seatbelted exposures as opposed to $42.7 \%$ of non-seatbelted exposures. There also appears to be a slight benefit concerning partial ejections; $6.0 \%$ of those seatbelted were partially ejected as opposed to $8.2 \%$ for the non-seatbelted group.

Ejection as a function of roll severity and seatbelt usage is presented in Tables 9 and 10. It appears from Table 9 that full ejection is slightly more prevelant with the far side seating position, despite that there were less far side exposures ( $45.5 \%$ to $54.5 \%$ for near side exposures), as reported in Table 4.

\begin{tabular}{|l|c|c|c|c|c|c|c|c|}
\hline \multicolumn{7}{|c|}{ Complete ejection } \\
\hline & \multicolumn{3}{|c|}{ Seatbelted } & \multicolumn{4}{c|}{ Non-seatbelted } \\
\hline $1 / 4$ turns & Near & Far & Tot & $\%$ & Near & Far & Tot & $\%$ \\
\hline $1 \& 2$ & 2 & 1 & 3 & 25.0 & 4 & 8 & 12 & 7.7 \\
\hline $3 \& 4$ & 0 & 1 & 1 & 8.3 & 24 & 27 & 51 & 32.9 \\
\hline $5 \& 6$ & 1 & 4 & 5 & 41.7 & 25 & 14 & 34 & 21.9 \\
\hline $7 \& 8$ & 0 & 2 & 2 & 16.7 & 12 & 16 & 28 & 18.1 \\
\hline$>8$ & 1 & 0 & 1 & 8.3 & 6 & 10 & 16 & 10.3 \\
\hline Total & 4 & 8 & 12 & & 74 & 81 & 155 & \\
\hline$\%$ & 33.3 & 66.7 & & & 45.5 & 54.4 & & \\
\hline Table 9. & $\begin{array}{l}\text { Full ejection of occupants as a function of seated position with } \\
\text { respect to the direction of roll and roll severity. }\end{array}$ \\
\hline
\end{tabular}

\begin{tabular}{|l|c|c|c|c|c|c|c|c|}
\hline \multicolumn{7}{|c|}{ Partial ejection } \\
\hline & \multicolumn{3}{|c|}{ Seatbelted } & \multicolumn{4}{|c|}{ Non-seatbelted } \\
\hline $\begin{array}{l}1 / 4 \\
\text { turns }\end{array}$ & Near & Far & Tot & $\%$ & Near & Far & Tot & $\%$ \\
\hline $1 \& 2$ & 11 & 4 & 15 & 27.7 & 4 & 6 & 10 & 34.5 \\
\hline $3 \& 4$ & 7 & 8 & 15 & 27.2 & 5 & 5 & 10 & 34.5 \\
\hline $5 \& 6$ & 4 & 4 & 8 & 14.8 & 3 & 4 & 7 & 24.1 \\
\hline $7 \& 8$ & 3 & 1 & 4 & 7.4 & 0 & 0 & 0 & 0 \\
\hline$>8$ & 5 & 7 & 12 & 22.2 & 2 & 0 & 2 & 6.0 \\
\hline Total & 30 & 24 & 54 & & 14 & 15 & 29 & \\
\hline
\end{tabular}

Table 10. Partial ejection of occupants as a function of seated position with respect to the direction of roll and roll severity.

Table 10 shows the distribution of partial ejections. Notably, more partial ejections are reported for seatbelted occupants in near side initial seated positions. It is interesting to note that $22.2 \%$ of seatbelted partial ejections occur

\begin{tabular}{|c|c|c|c|c|c|c|c|c|}
\hline \multicolumn{7}{|c|}{ Maximum Abreviated Injury Scale (MAIS) } \\
\hline & \multicolumn{7}{|c|}{ Seatbelted } & \multicolumn{5}{c|}{ Non-seatbelted } \\
\hline MAIS & Near & Far & Tot & $\%$ & Near & Far & Tot & $\%$ \\
\hline 0 & 95 & 77 & 172 & 18.2 & 21 & 20 & 41 & 11.5 \\
\hline 1 & 303 & 215 & 518 & 54.9 & 54 & 48 & 102 & 28.7 \\
\hline 2 & 72 & 48 & 120 & 12.7 & 30 & 26 & 56 & 15.8 \\
\hline 3 & 42 & 46 & 88 & 9.3 & 33 & 34 & 67 & 18.9 \\
\hline 4 & 8 & 18 & 26 & 2.8 & 18 & 18 & 36 & 10.1 \\
\hline 5 & 4 & 7 & 11 & 1.2 & 18 & 18 & 36 & 10.1 \\
\hline 6 & 6 & 2 & 8 & 0.8 & 6 & 11 & 17 & 4.8 \\
\hline Total & 530 & 413 & 943 & & 180 & 175 & 355 & \\
\hline Table 11. MAIS injury level based on position with respect to the roll
\end{tabular}
direction and seatbelt usage.

with roll severity of greater than 2 full rolls $(>8$ quarter turns), while Table 2 shows that less than $6 \%$ of the collisions result in more than two full 
rolls. Partial ejections of non-seatbelted occupants appear to be distributed proportionately to the distrubution of exposures, with respect to number of quarter rolls, reported in Table 2 .

The Maximum Abbreviated Injury Scale (MAIS) level for each occupant was tabulated based on position and seatbelt usage (Table 11).

Table 11 shows a distinct reduction in injury for seatbelted occupants, with nearly three quarters $(73.1 \%)$ reporting no injury (MAIS-0) or minor injury (MAIS-1), while nearly $60 \%(59.8 \%)$ of the non-seatbelted occupants had injury levels of MAIS-2 and above.

Roof crush for each occupant exposure as a function of roll direction is given in Table 12 .

\begin{tabular}{|c|c|c|c|c|}
\hline \multicolumn{5}{|c|}{ Roof crush } \\
\hline & \multicolumn{2}{|c|}{ Nearside } & \multicolumn{2}{c|}{ Farside } \\
\hline Roof crush (cm) & Count & $\%$ & Count & $\%$ \\
\hline 0 & 322 & 46.2 & 266 & 45.6 \\
\hline $1-7$ & 115 & 16.5 & 82 & 14.1 \\
\hline $8-14$ & 92 & 13.2 & 88 & 15.1 \\
\hline $15-29$ & 124 & 17.8 & 107 & 18.4 \\
\hline $30-45$ & 33 & 4.7 & 32 & 5.5 \\
\hline $46-60$ & 8 & 1.1 & 6 & 1.0 \\
\hline$>60$ & 3 & 0.4 & 2 & 0.3 \\
\hline Total & 697 & & 583 & \\
\hline
\end{tabular}

Table 12. Seatbelt usage as a function of passenger position in the vehicle.

Well over half $(61.3 \%)$ of the exposures had a roof crush of $7 \mathrm{~cm}$ or less. Roof crush of $30 \mathrm{~cm}$ and above is relatively rare, occurring in approximately $6.4 \%$ of the exposures. It is interesting to note that the distribution of roof crush is remarkably similar between near and far side exposures, a result which was not expected.

The most significant occupant injury, using the MAIS, was examined for each occupant, based on the roof crush. Table 13 presents data for seatbelted occupants and Table 14 presents data for non-seatbelted occupants. As expected, seatbelted and non-seatbelted occupant exposures had a similar roof crush distribution.

\begin{tabular}{|c|c|c|c|c|c|c|c|c|c|}
\hline \multicolumn{10}{|c|}{ Roof crush } \\
\hline & \multicolumn{7}{|c|}{ Seatbelted (All) } \\
\cline { 2 - 11 } & \multicolumn{7}{|c|}{ MAIS } \\
\hline R.C.(cm) & 0 & 1 & 2 & 3 & 4 & 5 & 6 & Tot & $\%$ \\
\hline 0 & 93 & 227 & 48 & 29 & 4 & 2 & 3 & 406 & 42.4 \\
\hline $1-7$ & 23 & 89 & 18 & 16 & 4 & 2 & 1 & 153 & 16.0 \\
\hline $8-14$ & 22 & 82 & 22 & 21 & 2 & 1 & 0 & 150 & 15.7 \\
\hline $15-29$ & 23 & 92 & 29 & 20 & 11 & 2 & 3 & 180 & 18.8 \\
\hline $30-45$ & 4 & 26 & 10 & 6 & 2 & 1 & 1 & 50 & 5.2 \\
\hline $46-60$ & 0 & 7 & 2 & 3 & 0 & 0 & 1 & 13 & 1.4 \\
\hline$>60$ & 0 & 3 & 2 & 0 & 0 & 1 & 0 & 6 & 0.6 \\
\hline Total & 165 & 526 & 131 & 95 & 23 & 9 & 9 & 958 & \\
\hline
\end{tabular}

Table 13. MAIS as a function of seatbelt usage and roof crush (including full and partially ejected occupants).

\begin{tabular}{|c|c|c|c|c|c|c|c|c|c|}
\hline \multicolumn{10}{|c|}{ Roof crush } \\
\hline & \multicolumn{10}{|c|}{ MAIS -seatbelted (All) } \\
\cline { 2 - 11 } & \multicolumn{10}{|c|}{} \\
\hline R.C.(cm) & 0 & 1 & 2 & 3 & 4 & 5 & 6 & Tot & $\%$ \\
\hline 0 & 20 & 48 & 21 & 30 & 14 & 15 & 8 & 156 & 41.5 \\
\hline $1-7$ & 9 & 14 & 7 & 11 & 4 & 3 & 2 & 50 & 13.3 \\
\hline $8-14$ & 5 & 18 & 9 & 6 & 7 & 5 & 2 & 52 & 13.8 \\
\hline $15-29$ & 8 & 21 & 19 & 17 & 12 & 10 & 3 & 90 & 23.9 \\
\hline $30-45$ & 2 & 3 & 2 & 3 & 6 & 4 & 2 & 22 & 5.9 \\
\hline $46-60$ & 1 & 0 & 2 & 2 & 0 & 0 & 0 & 5 & 1.3 \\
\hline$>60$ & 0 & 0 & 0 & 1 & 0 & 0 & 0 & 1 & 0.3 \\
\hline Total & 45 & 104 & 60 & 70 & 43 & 37 & 17 & 376 & \\
\hline
\end{tabular}

Table 14. MAIS as a function of seatbelt usage and roof crush (including full and partially ejected occupants).

\begin{tabular}{|c|c|c|c|c|c|c|c|c|c|}
\hline \multicolumn{10}{|c|}{ Roof crush } \\
\hline \multicolumn{10}{|c|}{ Seatbelted (Not ejected) } \\
\hline & \multicolumn{7}{|c|}{ MAIS } & & \\
\hline $\begin{array}{l}\text { R.C. } \\
(\mathrm{cm})\end{array}$ & 0 & 1 & 2 & 3 & 4 & 5 & 6 & Tot & $\%$ \\
\hline 0 & 90 & 218 & 43 & 22 & 4 & 2 & 2 & 381 & 43.4 \\
\hline $1-7$ & 23 & 87 & 18 & 11 & 3 & 0 & 0 & 142 & 16.2 \\
\hline $8-14$ & 22 & 76 & 20 & 20 & 1 & 0 & 0 & 139 & 15.8 \\
\hline $15-29$ & 23 & 87 & 23 & 15 & 6 & 1 & 3 & 158 & 18.0 \\
\hline $30-45$ & 4 & 25 & 6 & 3 & 1 & 1 & 0 & 40 & 4.6 \\
\hline $46-60$ & 0 & 7 & 2 & 3 & 0 & 0 & 1 & 13 & 1.5 \\
\hline$>60$ & 0 & 3 & 1 & 0 & 0 & 1 & 0 & 5 & 0.6 \\
\hline Total & 162 & 503 & 113 & 74 & 15 & 5 & 6 & 878 & \\
\hline
\end{tabular}

Table 15. MAIS as a function of seatbelt usage and roof crush (excluding full and partially ejected occupants. 
Table 15 and Table 16 present significant injury using the MAIS for seatbelted and non-seatbelted occupants based on the roof crush for non-ejected occupants.

\begin{tabular}{|c|c|c|c|c|c|c|c|c|c|}
\hline \multicolumn{10}{|c|}{ Roof crush } \\
\hline & \multicolumn{7}{|c|}{ Non-seatbelted (Not ejected) } & & \\
\hline & \multicolumn{7}{|c|}{ MAIS } & & \\
\hline R.C. $(\mathrm{cm})$ & 0 & 1 & 2 & 3 & 4 & 5 & 6 & Tot & $\%$ \\
\hline 0 & 16 & 40 & 7 & 12 & 3 & 3 & 0 & 81 & 45.5 \\
\hline $1-7$ & 7 & 11 & 3 & 3 & 1 & 0 & 0 & 25 & 14.0 \\
\hline $8-14$ & 3 & 14 & 4 & 2 & 2 & 1 & 0 & 26 & 14.6 \\
\hline $15-29$ & 5 & 18 & 8 & 3 & 2 & 0 & 0 & 36 & 20.2 \\
\hline $30-45$ & 0 & 3 & 1 & 2 & 0 & 1 & 1 & 8 & 4.9 \\
\hline $46-60$ & 0 & 0 & 1 & 1 & 0 & 0 & 0 & 2 & 1.1 \\
\hline$>60$ & 0 & 0 & 0 & 0 & 0 & 0 & 0 & 0 & 0.0 \\
\hline Total & 31 & 86 & 24 & 23 & 8 & 5 & 1 & 178 & \\
\hline
\end{tabular}

Table 17 and Table 18 present significant injury using the MAIS for seatbelted and non-seatbelted occupants based on the roof crush for fully ejected occupants

\begin{tabular}{|c|c|c|c|c|c|c|c|c|c|}
\hline \multicolumn{7}{|c|}{ Soof crush } \\
\hline & \multicolumn{7}{|c|}{ MAIS } \\
\cline { 2 - 11 } & \multicolumn{7}{|c|}{ Seatted (Fully ejected) } & \multicolumn{1}{c|}{} \\
\hline R.C.(cm) & 0 & 1 & 2 & 3 & 4 & 5 & 6 & Tot & $\%$ \\
\hline 0 & 0 & 2 & 0 & 2 & 0 & 0 & 1 & 5 & 38.5 \\
\hline $1-7$ & 0 & 0 & 0 & 2 & 0 & 1 & 0 & 3 & 23.1 \\
\hline $8-14$ & 0 & 1 & 1 & 0 & 0 & 0 & 0 & 2 & 15.4 \\
\hline $15-29$ & 0 & 0 & 0 & 1 & 1 & 0 & 0 & 2 & 15.4 \\
\hline $30-45$ & 0 & 0 & 0 & 0 & 1 & 0 & 0 & 1 & 7.7 \\
\hline $46-60$ & 0 & 0 & 0 & 0 & 0 & 0 & 0 & 0 & --- \\
\hline$>60$ & 0 & 0 & 0 & 0 & 0 & 0 & 0 & 0 & --- \\
\hline Total & 0 & 3 & 1 & 5 & 2 & 1 & 1 & 13 & \\
\hline
\end{tabular}

Table 19 and 20 present significant injury using the MAIS for seatbelted and non-seatbelted occupants based on the roof crush for partially ejected occupants.

\begin{tabular}{|c|c|c|c|c|c|c|c|c|c|}
\hline \multicolumn{7}{|c|}{ Noof crush } \\
\hline & \multicolumn{7}{|c|}{ MAIS } \\
\cline { 2 - 11 } & \multicolumn{1}{|c|}{ Neatbelted (Fully ejected) } & \multicolumn{1}{|c|}{} \\
\hline R.C.(cm) & 0 & 1 & 2 & 3 & 4 & 5 & 6 & Tot & $\%$ \\
\hline 0 & 4 & 7 & 11 & 14 & 11 & 11 & 5 & 63 & 37.3 \\
\hline $1-7$ & 2 & 2 & 4 & 6 & 3 & 3 & 1 & 21 & 12.4 \\
\hline $8-14$ & 1 & 3 & 4 & 3 & 5 & 4 & 2 & 22 & 13.0 \\
\hline $15-29$ & 3 & 1 & 11 & 13 & 7 & 9 & 2 & 46 & 27.2 \\
\hline $30-45$ & 2 & 0 & 1 & 1 & 5 & 3 & 1 & 13 & 7.7 \\
\hline $46-60$ & 1 & 0 & 1 & 1 & 0 & 0 & 0 & 3 & 1.8 \\
\hline$>60$ & 0 & 0 & 0 & 1 & 0 & 0 & 0 & 1 & 0.6 \\
\hline Total & 13 & 13 & 32 & 39 & 31 & 30 & 11 & 169 & \\
\hline
\end{tabular}

Table 18. MAIS for fully ejected occupants as a function of seatbelt usage and roof crush.

\begin{tabular}{|c|c|c|c|c|c|c|c|c|c|}
\hline \multicolumn{10}{|c|}{ Roof crush } \\
\hline & \multicolumn{7}{|c|}{ Seatbelted (Partial ejection) } & & \\
\hline & \multicolumn{7}{|c|}{ MAIS } & & \\
\hline R.C. $(\mathrm{cm})$ & 0 & 1 & 2 & 3 & 4 & 5 & 6 & Tot & $\%$ \\
\hline 0 & 3 & 6 & 5 & 5 & 0 & 0 & 0 & 19 & 31.1 \\
\hline $1-7$ & 0 & 2 & 0 & 3 & 1 & 1 & 1 & 8 & 13.1 \\
\hline $8-14$ & 0 & 5 & 1 & 1 & 1 & 1 & 0 & 9 & 14.8 \\
\hline $15-29$ & 0 & 3 & 6 & 4 & 3 & 0 & 0 & 16 & 26.2 \\
\hline $30-45$ & 0 & 1 & 3 & 3 & 0 & 0 & 1 & 8 & 13.1 \\
\hline $46-60$ & 0 & 0 & 0 & 0 & 0 & 0 & 0 & 0 & 0.0 \\
\hline$>60$ & 0 & 0 & 1 & 0 & 0 & 0 & 0 & 1 & 1.6 \\
\hline Total & 3 & 17 & 16 & 16 & 5 & 2 & 2 & 61 & \\
\hline
\end{tabular}

\begin{tabular}{|c|c|c|c|c|c|c|c|c|c|}
\hline \multicolumn{10}{|c|}{ Roof crush } \\
\hline & \multicolumn{7}{|c|}{ Non-seatbelted (Partial ejection) } & & \\
\hline & \multicolumn{7}{|c|}{ MAIS } & & \\
\hline R.C. $(\mathrm{cm})$ & 0 & 1 & 2 & 3 & 4 & 5 & 6 & Tot & $\%$ \\
\hline 0 & 0 & 1 & 3 & 4 & 0 & 1 & 3 & 12 & 41.4 \\
\hline $1-7$ & 0 & 1 & 0 & 2 & 0 & 0 & 1 & 4 & 13.8 \\
\hline $8-14$ & 1 & 1 & 1 & 1 & 0 & 0 & 0 & 4 & 13.8 \\
\hline $15-29$ & 0 & 2 & 0 & 1 & 3 & 1 & 1 & 8 & 27.6 \\
\hline $30-45$ & 0 & 0 & 0 & 0 & 1 & 0 & 0 & 1 & 3.4 \\
\hline $46-60$ & 0 & 0 & 0 & 0 & 0 & 0 & 0 & 0 & 0.0 \\
\hline$>60$ & 0 & 0 & 0 & 0 & 0 & 0 & 0 & 0 & 0.0 \\
\hline Total & 1 & 5 & 4 & 8 & 4 & 2 & 5 & 29 & \\
\hline
\end{tabular}

To determine if seatbelted occupants experience a lower injury level than non-seatbelted non-ejected occupants, the MAIS mean and standard deviation 
for all seatbelted occupants and all roof crush levels was calculated for all seatbelted occupants (Table 13) and non-seatbelted/not ejected occupants (Table 16). It was determined that all seatbelted occupants had a mean MAIS of 1.318 (S.D. $=1.097)$ while non-seatbelted/not ejected occupants had a mean of 1.494 (S.D.= 1.258). The statistical analysis (t-test) demonstrates that the seatbelted group had a significantly lower maximum injury level than their nonseatbelted/not ejected counterparts $(p=0.041)$.

To examine significant injuries between seatbelted and non-seatbelted occupants as a function of roof crush, injuries of MAIS 3 and above were considered and presented in Table 21 (all exposures), Table 22 (non-ejected exposures), Table 23 (fully ejected exposures) and Table 24 (partial ejected exposures).

\begin{tabular}{|c|c|c|c|c|c|c|}
\hline \multicolumn{5}{|c|}{ All exposures, including partial and full ejection } \\
\hline & \multicolumn{3}{|c|}{ Seatbelted } & \multicolumn{3}{c|}{ Non-seatbelted } \\
\hline \multirow{2}{*}{ R.C.(cm) } & \multirow{2}{*}{ Total } & \multicolumn{2}{|c|}{ MAIS $\geq 3$} & \multirow{2}{*}{ Total } & \multicolumn{2}{c|}{ MAIS $\geq 3$} \\
\cline { 3 - 4 } \cline { 5 - 7 } & & Count & $\%$ & & Count & $\%$ \\
\hline 0 & 406 & 38 & 9.4 & 156 & 67 & 42.9 \\
\hline $1-7$ & 153 & 23 & 15.0 & 50 & 20 & 40.0 \\
\hline $8-14$ & 150 & 25 & 16.7 & 52 & 20 & 38.5 \\
\hline $15-29$ & 180 & 36 & 20.0 & 90 & 42 & 46.7 \\
\hline $30-45$ & 50 & 10 & 20.0 & 22 & 15 & 68.2 \\
\hline $46-60$ & 13 & 4 & 30.8 & 5 & 2 & 40.0 \\
\hline$>60$ & 6 & 1 & 16.7 & 1 & 1 & 100.0 \\
\hline
\end{tabular}

Table 21. Seatbelted and non-seatbelted exposures and most serious injury of AIS 3 and above (MAIS 3 and above) as a function of roo crush..

As can be seen from Table 21, there is an increasing trend for the percentage of MAIS 3 and above injury per exposure with increasing roof crush. In every case, the fraction of MAIS 3 and above injury is less for seatbelted occupants, regardless of roof crush. A statistical analysis (chi-square) was performed for each category of crush level. Seatbelted occupants had significantly less $(\mathrm{p}<0.05)$ MAIS 3 and above injuries for all catagories of roof crush less than $46 \mathrm{~cm}$. Of note, the data above $46 \mathrm{~cm}$ of crush is relatively sparse. While the same trend exists, it did not reach the $p<0.05$ level of significance.

\begin{tabular}{|c|c|c|c|c|c|c|}
\hline \multicolumn{7}{|c|}{ Exposures, excluding partial and full ejection } \\
\hline \multirow{3}{*}{ R.C. $(\mathrm{cm})$} & \multicolumn{3}{|c|}{ Seatbelted } & \multicolumn{3}{|c|}{ Non-seatbelted } \\
\hline & \multirow{2}{*}{ Total } & \multicolumn{2}{|c|}{ MAIS $\geq 3$} & \multirow{2}{*}{ Total } & \multicolumn{2}{|c|}{ MAIS $\geq 3$} \\
\hline & & Count & $\%$ & & Count & $\%$ \\
\hline 0 & 381 & 30 & 7.9 & 81 & 18 & 22.2 \\
\hline $1-7$ & 142 & 14 & 9.9 & 25 & 4 & 16.0 \\
\hline 8-14 & 139 & 21 & 15.1 & 26 & 5 & 19.2 \\
\hline $15-29$ & 158 & 25 & 15.8 & 36 & 5 & 13.8 \\
\hline $30-45$ & 40 & 5 & 12.5 & 8 & 4 & 50.0 \\
\hline $46-60$ & 13 & 4 & 30.8 & 2 & 1 & 50.0 \\
\hline$>60$ & 5 & 1 & 20.0 & 0 & 0 & ---- \\
\hline Total & 878 & 100 & & 178 & 37 & \\
\hline
\end{tabular}

Table 22 again shows a similar trend of an increasing fraction with MAIS 3 or greater injury as roof crush increases for seatbelted drivers and a less persuasive trend for non-seatbelted drivers. Again, the percentage of MAIS 3 and above injuries was greater for all crush level categories except the 15-29 cm category, for the nonseatbelted drivers. The statistical tests show that the $15-29 \mathrm{~cm}$ category and the two categories greater than $46 \mathrm{~cm}$ did not reach the $\mathrm{p}<0.05$ level of significance.

\begin{tabular}{|c|c|c|c|c|c|c|}
\hline \multicolumn{5}{|c|}{ Full ejection exposures } \\
\hline & \multicolumn{3}{|c|}{ Seatbelted } & \multicolumn{3}{c|}{ Non-seatbelted } \\
\hline \multirow{2}{*}{ R.C.(cm) } & \multirow{2}{*}{ Total } & \multicolumn{2}{|c|}{ MAIS $\geq 3$} & \multicolumn{2}{|c|}{ Total $\geq 3$} \\
\cline { 3 - 4 } \cline { 4 - 7 } & & Count & $\%$ & & Count & $\%$ \\
\hline 0 & 5 & 3 & 60.0 & 63 & 41 & 65.1 \\
\hline $1-7$ & 3 & 3 & 100.0 & 21 & 13 & 61.2 \\
\hline $8-14$ & 2 & 0 & 0.0 & 22 & 14 & 63.6 \\
\hline $15-29$ & 2 & 2 & 100.0 & 46 & 31 & 67.4 \\
\hline $30-45$ & 1 & 1 & 100.0 & 13 & 10 & 76.9 \\
\hline $46-60$ & 0 & 0 & ---- & 3 & 1 & 33.3 \\
\hline$>60$ & 0 & 0 & ---- & 1 & 1 & 100.0 \\
\hline
\end{tabular}

Table 23. Fully ejected, seatbelted and non-seatbelted exposures and most serious injury of AIS 3 and above (MAIS 3 and above) as a function of roof crush.

Table 23 suggests that full ejection with a seatbelt has a very high probablility of causing a MAIS 3 or above injury. Full ejection without a seatbelt results in an MAIS 3 or greater injury approximately $2 / 3$ of the time. 


\begin{tabular}{|c|c|c|c|c|c|c|}
\hline \multicolumn{7}{|c|}{ Partial ejection exposures } \\
\hline \multirow{3}{*}{ R.C. $(\mathrm{cm})$} & \multicolumn{3}{|c|}{ Seatbelted } & \multicolumn{3}{|c|}{ Non-seatbelted } \\
\hline & \multirow{2}{*}{ Total } & \multicolumn{2}{|c|}{ MAIS $\geq 3$} & \multirow{2}{*}{ Total } & \multicolumn{2}{|c|}{ MAIS $\geq 3$} \\
\hline & & Count & $\%$ & & Count & $\%$ \\
\hline 0 & 19 & 5 & 26.3 & 12 & 8 & 66.7 \\
\hline $1-7$ & 8 & 6 & 75.0 & 4 & 3 & 75.0 \\
\hline $8-14$ & 9 & 3 & 33.3 & 4 & 1 & 25.0 \\
\hline $15-29$ & 16 & 7 & 43.8 & 8 & 4 & 50.0 \\
\hline $30-45$ & 8 & 4 & 50.0 & 1 & 1 & 100.0 \\
\hline $46-60$ & 0 & 0 & --- & 0 & 0 & ---- \\
\hline$>60$ & 1 & 1 & 100.0 & 0 & 0 & ---- \\
\hline
\end{tabular}

Table 24 would seem to suggest that in a partial ejection, there may be some slight advantage to being seatbelted. The data, however is relatively sparse to base conclusions.

Fatal injury data are presented in Table 25.

\begin{tabular}{|l|c|c|c|c|c|c|}
\hline \multicolumn{7}{|c|}{ Fatal injury } \\
\hline \multirow{2}{*}{ Ejection } & \multicolumn{3}{|c|}{ Seatbelted } & \multicolumn{3}{c|}{ Non-seatbelted } \\
\cline { 2 - 8 } & Exposures & Fatal & $\%$ & Exposures & Fatal & $\%$ \\
\hline None & 889 & 18 & 2.0 & 189 & 5 & 2.6 \\
\hline Partial & 62 & 12 & 19.4 & 31 & 18 & 58.1 \\
\hline Full & 13 & 4 & 30.8 & 173 & 62 & 35.8 \\
\hline Unk & 9 & 1 & 11.1 & 0 & 0 & \\
\hline Totals & 973 & 35 & 3.6 & 393 & 85 & 21.6 \\
\hline
\end{tabular}

Table 25. Fatal injury for seatbelted and non-seatbelted occupants based on ejection status.

As can be seen in Table 25 the overall nonseatbelted fatality rate is approximately 6 times that of the seatbelted fatality rate (21.6/3.6). There also appears to be a benefit to seatbelt usage in all ejection catagories, particularly the partially ejected category.

Fatalities of seatbelted non-ejected occupants were examined to determine their cause. While the information is generally incomplete, it is significant to note that in 4 cases of a total of 18 , positional axphixiation, compression axphixiation or suffocation was listed as the cause or a potentially contributing factor to the cause of death.

The body region of serious (AIS 3 or above) injuries was tabulated as a function of seatbelt usage in Table 26.

\begin{tabular}{|c|c|c|c|c|}
\hline \multicolumn{2}{|c|}{ Area of body with AIS 3 and above injury } \\
\hline & \multicolumn{2}{|c|}{ Seatbelted } & \multicolumn{2}{c|}{ Non-seatbelted } \\
\hline Body region & Count & $\%$ & Count & $\%$ \\
\hline Head & 42 & 28.2 & 81 & 46.8 \\
\hline Face & 2 & 1.3 & 3 & 1.7 \\
\hline Neck & 0 & 0 & 0 & 0 \\
\hline Spine & 3 & 2.0 & 7 & 4.0 \\
\hline Upper extremity & 23 & 15.4 & 8 & 4.6 \\
\hline Thorax & 47 & 31.5 & 41 & 23.7 \\
\hline Pelvic/abdomen & 17 & 11.4 & 16 & 9.2 \\
\hline Lower extremity & 13 & 8.7 & 17 & 9.8 \\
\hline External & 2 & 1.3 & 0 & 0 \\
\hline Total & 149 & & 173 & \\
\hline
\end{tabular}

Table 26. Body region of serious injury (AIS 3 and above).

As can be seen by Table 26, non-seatbelted occupants have significantly higher AIS 3 and above head injuries, as compaired to seatbelted occupants. It should also be noted that there was a fewer incidence of AIS 3 and above injury for seatbelted occupants, despite that approximately $72 \%$ of total exposures involved seatbelted occupants.

\section{DISCUSSION}

In this study, approximately $72 \%$ of the included occupants were restrained with the installed seatbelt. This is consistent with the general trend of seatbelt usage. Paranteau (2001, 2000) reported a seatbelt usage rate of approximately $71 \%$ based on NASS/CDS rollover data for the years 1992 through 1998 and $74.4 \%$ based on NASS/CDS rollover data for the years 1992 throught 1996.

In this study, the fatality rate for non-ejected occupants was $2.0 \%$ for those seatbelted and 2.6 $\%$ for those non-seatbelted. The fatality rate for partially ejected occupants was $19.4 \%$ for those seatbelted and $58.1 \%$ for those non-seatbelted and for fully ejected occupants, $30.8 \%$ for those seatbelted and $35.8 \%$ for those non-seatbelted. Ejection status has the largest effect on the fatality rate.

Seatbelts are highly effective in preventing ejection. In this study approximately $7.5 \%$ of seatbelted occupants were partially or fully 
ejected as compared to $51.2 \%$ of the nonseatbelted occupants.

The rate of serious injury appears to increase with roof crush, likely as a result of increased severity, as suggested by Friedman, et.al. (1998). This trend is seen with both seatbelted and nonseatbelted exposures. Serious injuries are clearly more prevalent with non-seatbelted occupants when ejection exposures are included. When only non-ejected exposures are included, as a trend, the seatbelted occupants tend to have less severe injuries; however, not all of the roof crush depth categories reached a statistical level of significance of $p<0.05$. In particular, the data is limited with roof crush levels over $46 \mathrm{~cm}$ and therefore was insufficient for statistical significance.

It should be noted that this study was performed using a wide variety of SUV types and years of manufacture. Current research suggests that increased post rollover headroom and not necessarily decreased roof crush reduces the severity of injury. This study, however, helps to dispell the notion that occupants somehow have reduced their injury potential by being unrestrained, because of the magnitude of the roof crush.

This study presents unweighted data and includes both the number of exposures as well as those exposures which met the noted criteria. Because it is unweighted data, the percentages of all accidents, represented by weighted data, may vary somewhat from that presented. Limited statistical analyses were performed as noted.

\section{CONCLUSION}

In this study, approximately $72 \%$ of the occupants were seatbelted. Seatbelts were highly effective in minimizing ejection (both partial and full), with only $7.5 \%$ ejection rate for seatbelted occupants as compaired with $54.4 \%$ of non-seatbelted occupants. Ejection is the single best predictor of serious or fatal injuries. For example, nonseatbelted occupants were 6.2 times more likely to receive fatal injuries than their seatbelted counterparts. Seatbelted occupants had less severe injuries than their non-seatbelted counterparts, regardless of roll direction, number of rolls or roof crush, when exposure to ejection is included.
Even when only non-ejected exposures were considered, the injury rate and severity of seatbelted occupants tended to be less than that for the non-seatbelted occupants.

\section{REFERENCES}

1. Bahling, G.S., Bundorf, R.T., Kaspzyk, G.S., Moffatt, Orlowski, K.F., and Stocke, J.E., "Rollover and Drop Tests -The Influence of Roof Strength on Injury Mechanics Using Belted Dummies", SAE Paper 902314, SAE International, Warrendale, PA, 1990.

2. Deutermann, William, "Characteristics of Fatal Rollover Crashes", NHTSA, DOT HS 809 438, April 2002.

3. Diggs, Kennerly, Malliaris, A.C., "Crashworthiness Safety Features in Rollover Crashes", SAE paper 982296, SAE International, Warrendale, PA, 1998.

4. Esterlitz, J.R., "Relative Risk of Death from Ejection by Crash Type and Crash Mode", Accident Analysis and Prevention, Vol. 21, No. 5, pp 459-468, 1989.

5. Freidman, Donald, Friedman, Keith, "Roof Crush Versus Occupant Injury from 1988 to 1992 NASS", SAE paper 980210, SAE International, Warrendale, PA, 1998.

6. Godrick, Daniel A, "Analysis of NASS Cases involving SUV Rollovers with Belted and Unbelted Occupants", FHWA/NHTSA National Crash Analysis Center report May 2002.

7. Moffatt, E.A., Cooper, E.R., Cronteau, J.J., Orlowski, K.F., Marth, D.R., and Carter, J.W., "Matched-Pair Rollover Impacts of Rollcaged and Production Roof Cars Using the Controlled Rollover Impact System (CRIS)", SAE paper 2003-01-0172, SAE International, Warrendale, PA, 2003.

8. Orlowski, Kenneth F., Bundorf, R. Thomas \& Moffatt, Edward A., "Rollover Crash Tests -The Influence of Roof Strength on Injury Mechanics", SAE paper 851734, SAE International, Warrendale, PA, 1985.

9. Paranteau, Chantal, and Shah, Minoo, "Driver Injuries in US Single-Event Rollovers", SAE paper 2000-010633, SAE International, Warrendale, PA, 2000.

10. Paranteau, Chantal, Gopal, Madana, and Viano, David, "Near and Far-Side Adult Front Passenger Kinematics in a Vehicle Rollover", SAE paper 2001-01-0176, SAE International, Warrendale, PA, 2001.

11. Piziali, Robert, Hopper, Robert, Girvan, Daniel, and Merala, Raymond, "Injury Causation in Rollover Accidents and the Biofedelity of Hybrid III Data in Rollover Tests", SAE paper 980362, SAE International, Warrendale, PA, 1998. 


\section{CONTACT}

Orion P. Keifer

Applications Engineering Group, Inc. (AEGI)

1200 Mayport Road

Atlantic Beach, Florida 32233

800-777-7668

opk@aegiforensics.com 